\title{
Prognostic Values of Fluctuations in Serum Levels of Alanine Transaminase in Inactive Carrier State of HBV Infection
}

\author{
Hossein Farzi ${ }^{1}$; Nasser Ebrahimi Daryani ${ }^{1}$; Leila Mehrnoush ${ }^{2}$; Shima Salimi ${ }^{2}$; Seyed Moayed \\ Alavian ${ }^{2, *}$ \\ ${ }^{1}$ Department of Gastroenterology and Hepatology, Tehran University of Medical Sciences, Tehran, IR Iran \\ ${ }^{2}$ Middle East Liver Diseases Center (MELD), Tehran, IR Iran \\ *Corresponding Author: Seyed Moayed Alavian, Middle East Liver Diseases Center (MELD), Tehran, IR Iran. Tel: +98-2188067114, Fax: +98-2188067114, E-mail: editor@epatmon.com
}

Received: January 12, 2014; Revised: February 22, 2014; Accepted: February 23, 2014

\begin{abstract}
Background: Current guidelines introduce periodic monitoring of serum alanine transaminase (ALT) as the first-line modality in follow-up patients, with a hepatitis B virus (HBV) inactive carrier state.

Objectives: This study aimed to determine the incidence rate and patterns of ALT fluctuations and prognostic values for the development of chronic HBV e antigen (HBeAg)-negative hepatitis B (CHB), HBV surface antigen (HBsAg) seroclearance, and liver-related complications. Patients and Methods: Treatment-naïve patients with a chronic HBV infection, $\mathrm{HBeAg}(-) / \mathrm{HBeAb}(+)$, normal ALT levels, and $\mathrm{HBV}$ DNA < $2000 \mathrm{IU} / \mathrm{mL}$, were followed-up every 6-12 months by assessing serum ALT levels. Serum HBV DNA was measured in cases of elevated ALT levels.

Results: A total of 399 patients were followed-up for 8.9 years; ALT > upper limit of normal (ULN, i.e. 40 IU/L) was detected in 103 (25.8\%) patients, with an annual incidence rate of $2.9 \%$. ALT elevation was associated with; male gender, age, and higher serum ALT levels at study entry. Among the cases of ALT elevations, 16 (15.5\%) patients had ALT levels $>2 \times$ ULN. There were 38 (36.9\%) patients who had ALT levels that remained > ULN over six months, and 21 (20.4\%) patients experienced at least two episodes of ALT elevations. In 15 (14.6\%) patients, elevated ALT levels were associated with increased HBV replication (i.e. HBV DNA > $2000 \mathrm{IU} / \mathrm{mL}$ ) and these were considered as CHB. However, elevation of ALT levels, even in the absence of HBV replication, increased the risk for the development of CHB up to 8-fold in prospective follow-ups. HBsAg seroclearance, cirrhosis, and hepatocellular carcinoma were detected in 43 (10.8\%), 4 (1\%), and 1 (0.25\%) patients, respectively.
\end{abstract}

Conclusions: Fluctuations in serum ALT levels may change the prognosis of a HBV inactive carrier state.

Keywords: Hepatitis B Virus; Alanine Transaminase; Hepatitis B e Antigen; Hepatitis B, Chronic

\section{Background}

Hepatitis B virus (HBV) infection is one of the major health challenges worldwide, and it is estimated to affect more than 350 million chronic carriers globally (1). Chronic infection with the virus may cause a wide spectrum of outcomes and complications that vary from an inactive carrier state to active chronic hepatitis, and from normal liver function to cirrhosis, hepatocellular carcinoma (HCC), and liver-related death (2).

The inactive carrier state, is the most prevalent subtype of chronic HBV infection (3), and it is mainly defined by the absence of the hepatitis $\mathrm{B}$ e antigen (HBeAg), presence of the hepatitis B e antibody (HBeAb), low levels of viremia (i.e. HBV DNA $<2000 \mathrm{IU} / \mathrm{mL}$ ), and persistently normal levels of alanine transaminase (ALT) in the serum $(4,5)$. Patients in an inactive carrier state, in comparison with patients with chronic HBV hepatitis, are considered to show a benign course of the disease with; minor histo- pathologic damage to liver tissue (6-9), and a lower incidence of cirrhosis (10), or HCC (11).

However, several studies have reported that patients in an inactive carrier state, compared to normal healthy control populations, may be at higher risk for developing liver histopathologic changes (12), HCC, and liver-related death (1). Moreover, it has frequently been reported that patients with an inactive carrier state may experience reactivation of the infection into chronic HBeAg negative hepatitis, with an annual incidence rate of 1 to 3 per 100 patients (13). Although the natural history of patients with an inactive carrier state is relatively well characterized, the incidence of complications previously described above has led to questions with regard to the identification of prognostic risk factors in these patients. It has been reported that advanced age at study entry $(14,15)$, male gender (14-16), HBV DNA $\geq 1000 \mathrm{IU} / \mathrm{mL}$ at study en-

Implication for health policy/practice/research/medical education:

This study hypothesized that incidence and patterns of fluctuations in serum levels of alanine transaminase in patients with HBV inactive carrier state may have prognostic implications. The findings of this study may provide an upgraded understanding of natural course of chronic hepatitis B virus infection.

Copyright (C) 2014, Kowsar Corp.; Published by Kowsar Corp. This is an open-access article distributed under the terms of the Creative Commons Attribution License, which permits unrestricted use, distribution, and reproduction in any medium, provided the original work is properly cited. 
try (16), HBsAg level $\geq 1000 \mathrm{IU} / \mathrm{mL}$ at study entry (17), and genotype $B(16)$, or C (18), of the virus may increase the risk for reactivation of the infection into chronic HBeAg negative hepatitis. Currently, chronic HBeAg negative hepatitis is characterized by periodic reactivation of the infection and active hepatitis, which is associated with elevated levels of liver aminotransferases and HBV DNA (4). Overall, according to the benign natural history of patients with an inactive carrier state, current guidelines such as the American Association for the Study of Liver Diseases (AASLD) and the European Association for the Study of the Liver (EASL), suggest that these patients may not need immediate antiviral therapy, and advice for periodic follow-ups and frequent monitoring of serum ALT levels is sufficient $(4,5)$.

\section{Objectives}

In this study, we aimed to evaluate the prevalence and patterns of ALT fluctuations over periodic follow-ups of patients with an inactive HBV carrier state. We also investigated the probable associations between enzyme fluctuations and disease outcomes.

\section{Patients and Methods}

\subsection{Study Design and Patient Population}

This study took place from 2000 to 2013, and it was designed to follow-up patients with chronic HBV infections (i.e. HBsAg positive $>6$ months) who were in an inactive carrier state and registered at the Tehran Hepatitis Center (THC: the outpatient clinic of the Baqiyatallah Research Center for Gastroenterology and Liver Diseases, Tehran, Iran). Inactive carrier state was defined as; HBeAg negative, HBeAb positive, HBV DNA $<2000 \mathrm{IU} / \mathrm{mL}$ at study entry, and persistently normal levels of ALT through the first year of follow-up. Initial assessment of the patients included; detailed medical history and physical examination, familial history of liver disease or HCC, complete blood count with platelets, prothrombin time (PT), serum albumin, aspartate transaminase (AST), alanine aminotransferase (ALT), alkaline phosphatase (ALP), HBeAg/ anti-HBe, HBV DNA, and abdominal ultrasonography. Patients with any of the following criteria were excluded from the study: history of receiving anti-HBV therapy; regular alcohol consumption; immunosuppressed patients (receiving immunosuppressive drugs, end stage renal disease and hemodialysis); thalassemia major; coinfection with HCV, HDV or HIV; concurrent liver diseases (cirrhosis, Wilson's disease, autoimmune hepatitis, $\alpha-1$-antitrypsin deficiency, biopsy proven non-alcoholic fatty liver disease or steatohepatitis) and abnormal findings through laboratory tests and ultrasonography at study entry. Informed consent was obtained from all participants in the study; and study protocols conformed to the ethical guidelines of the 1975 Declaration of Helsinki. Patients were followed up every 6 to 12 months by assessing serum ALT levels; and annually with HBV serological markers (HBsAg, HBeAg). In cases of ALT > upper limit of normal (ULN, i.e. $>40 \mathrm{IU} / \mathrm{L}$ ), serum HBV DNA was measured. Maximal serum ALT levels, frequency of ALT elevations and duration of each episode of ALT elevation were recorded. Drug induced hepatotoxicity or super-infection of HCV, HDV or HIV were evaluated in suspicious cases. Levels of liver aminotransferases were evaluated using standard ELISA kits (ULN = 40 IU/L). Serum HBV DNA levels were assessed by quantitative polymerase chain reaction assay (Cobas Amplicor HBV Monitor, Roche Diagnostics, sensitivity 200 copies $/ \mathrm{mL}$, conversion factor $=5.26$ ).

\subsection{Study Endpoints}

Patients with ALT > ULN and HBV DNA > $2000 \mathrm{IU} / \mathrm{ml}$; whether HBeAg negative or positive, were considered as chronic hepatitis B (CHB). The decision to initiate antiHBV therapy was made upon clinical evaluation, liver biopsy findings, or vibration-controlled transient elastography test (FibroScan 502 Touch, Echosens, USA). HBsAg seroclearance was defined as negative results for serum HBsAg on two consecutive occasions at least six months apart, which were maintained to the end of the study, with undetectable serum HBV DNA, and normal ALT levels. HBsAg seroclearance with development of HBsAb was considered as HBsAg seroconversion. Screening and diagnosis of cirrhosis and HCC were performed according to the previously described protocol (19).

\subsection{Statistical Analysis}

Quantitative variables were described as mean \pm standard deviation (SD). Independent and paired-samples ttest, chi-square, and linear and binary logistic regression tests, were applied in cases of relevance. Descriptive and analytic statistics were performed using SPSS software version 19 (IBM Corporation; NY; USA). Differences or correlations (Pearson's or Spearman's) with $\mathrm{P}<0.05$ were considered statistically significant.

\section{Results}

\subsection{Baseline Characteristics}

Initially, 447 patients met our inclusion criteria. Considering exclusion criteria; 399 inactive hepatitis B carriers with normal serum ALT levels and HBV DNA $<2000$ IU/ $\mathrm{mL}$, were included in the study; 231 (57.9\%) males and 168 (42.1\%) females. Mean age for the patients diagnosed with a HBV chronic infection and at study entrance were 33.55 \pm 11.64 and $35.57 \pm 11.56$ years, respectively. Patients were followed up for a mean period of 107.0 \pm 32.8 months; ie, $8.9 \pm 2.7$ years. The period of follow-up in male patients was longer than for the females; $111.6 \pm 36.2$ vs. $100.5 \pm 26.3$ 
Farzi H et al.

months $(\mathrm{P}<0.001)$. Serum levels of AST, ALT, and ALP at study entry were $24.4 \pm 7.8,24.0 \pm 9.4$, and $171.3 \pm 96.9 \mathrm{IU} / \mathrm{l}$, respectively. No statistically significant association was found between age or HBV DNA at study entry, and serum levels of AST ( $\mathrm{P}=0.92,0.66$, respectively) or ALT $(\mathrm{P}=0.16$, 0.21 , respectively). However, compared to females, male patients had higher levels of serum AST (26.0 \pm 7.9 vs. 22.4 $\pm 7.0, \mathrm{P}<0.001)$ and ALT levels $(26.9 \pm 9.3$ vs. $20.0 \pm 7.9 \mathrm{IU} / \mathrm{L}$, $\mathrm{P}<0.001)$.

At study entry, 166 (41.6\%) patients had undetectable serum HBV DNA. Mean serum viral load in 233 (58.4\%) patients with detectable HBV DNA was 492.1 $\pm 559.4 \mathrm{IU} / \mathrm{mL}$. No significant statistical correlation was found between; gender, age, AST, ALT or ALP levels at study entry, and detectable/undetectable HBV DNA, or quantitative PCR Hepatitis $\mathrm{B}$ viral load $(\mathrm{P}>0.05)$.

\subsection{Natural Course of ALT Fluctuations}

Through 3557 person-years of follow-up, 296 (74.2\%) patients had persistently normal levels of serum ALT, while $103(25.8 \%)$ patients experienced at least one episode of
ALT > ULN with an annual incidence rate of $2.89 \%$. Among patients with ALT elevation, in 87 (84.5\%), 10 (9.7\%), and 6 (5.8\%) persons, maximal serum ALT levels were within the range of 1-2 $\times$ ULN, 2-3 $\times$ ULN, and 3-4 $\times$ ULN, respectively. In $65(63.1 \%)$ patients, ALT levels decreased to normal levels within six months; while in 38 (36.9\%) patients, ALT levels remained over ULN for at least six months. Furthermore, $21(20.4 \%)$ patients experienced at least two episodes of ALT elevations. The association between patterns of ALT fluctuations and probable underlying risk factors were evaluated and demonstrated in Table 1 . Briefly, elevation of ALT > ULN had a significant statistical association with male gender $(\mathrm{P}<0.001, \mathrm{RR}=2.7,95 \%$ confidence interval $[\mathrm{CI}]=1.8-4.1)$, lower age at study entry (33.4 \pm 10.0 vs. $36.3 \pm$ 11.9 years, $P=0.015)$, and higher serum ALT levels at study entry (28.8 \pm 10.5 vs. $22.3 \pm 8.3 \mathrm{IU} / \mathrm{L}, \mathrm{P}<0.001)$. In patients with ALT $\leq 10 \mathrm{IU} / \mathrm{L}$, the cumulative incidence of enzyme elevation was $10.5 \%$; compared to $50.0 \%$ in patients with ALT $\geq 30 \mathrm{IU} / \mathrm{l}$ at study entry (Figure 1 ). Mean level of serum ALT at the end of study was $26.33 \pm 15.8 \mathrm{IU} / \mathrm{L}$; ranging from 4 to $140 \mathrm{IU} / \mathrm{L}$. ALT levels were significantly higher in the male patients $(30.9 \pm 18.2$ vs. $20.0 \pm 8.3 \mathrm{IU} / \mathrm{l}, \mathrm{P}<0.001)$.

Table 1. Patterns of Serum ALT Fluctuations in Inactive HBV Carrier State ${ }^{a}, \mathrm{~b}, \mathrm{c}$

\begin{tabular}{|c|c|c|c|c|c|c|}
\hline & \multirow{2}{*}{$\begin{array}{c}\text { Persistently Normal } \\
\text { ALT Levels }\end{array}$} & \multicolumn{3}{|c|}{ Maximal Serum ALT Levels } & \multirow{2}{*}{$\begin{array}{l}\text { Presence of ALT } \\
>6 \text { Months }\end{array}$} & \multirow{2}{*}{$\begin{array}{l}\geq 2 \text { Episodes of } \\
\text { ALT Elevations }\end{array}$} \\
\hline & & $>$ ULN & $>2 \times$ ULN & $>3 \times$ ULN & & \\
\hline Total number & 296 & 103 & 16 & 6 & 38 & 21 \\
\hline \multicolumn{7}{|l|}{ Gender } \\
\hline Male & $150(50.7)$ & $81(78.6)$ & $10(62.5)$ & $5(83.3)$ & $33(86.8)$ & $18(85.7)$ \\
\hline Female & $146(49.3)$ & $22(21.4)$ & $6(37.5)$ & $1(16.7)$ & $5(13.2)$ & $3(14.3)$ \\
\hline Pvalue & & $<0.001^{d}$ & 0.36 & 0.21 & $<0.001^{d}$ & $0.002^{\mathrm{e}}$ \\
\hline
\end{tabular}

\section{Family history of}

HBV infection

\begin{tabular}{|c|c|c|c|c|c|c|}
\hline Positive & 141 of $173(81.5)$ & 39 of $53(73.6)$ & 8 of $10(80)$ & 3 of $3(100)$ & 17 of $21(55.3)$ & 8 of $11(72.7)$ \\
\hline Negative & 32 of $173(18.5)$ & 14 of $53(26.4)$ & 2 of $10(20)$ & - & 4 of $21(19)$ & 3 of $11(27.3)$ \\
\hline P-value & - & 0.21 & 0.9 & 0.41 & 0.95 & 0.47 \\
\hline Age at study entry, y & $36.3 \pm 12.0$ & $33.4 \pm 10.0$ & $31.2 \pm 10.4$ & $35.8 \pm 8.4$ & $31.9 \pm 8.8$ & $29.4 \pm 9.0$ \\
\hline P-value & - & $0.018^{\mathrm{f}}$ & 0.09 & 0.91 & $0.008^{e}$ & $0.003^{\mathrm{e}}$ \\
\hline $\begin{array}{l}\text { Serum AST at study } \\
\text { entry, IU/L }\end{array}$ & $23.9 \pm 7.9$ & $25.9 \pm 7.2$ & $24.8 \pm 5.4$ & $25.5 \pm 4.5$ & $26.3 \pm 7.4$ & $27.2 \pm 8.0$ \\
\hline P-value & - & $0.026 \mathrm{f}$ & 0.68 & 0.62 & 0.08 & 0.068 \\
\hline $\begin{array}{l}\text { Serum ALT at study } \\
\text { entry, IU/L }\end{array}$ & $22.3 \pm 8.3$ & $28.5 \pm 10.3$ & $25.4 \pm 8.9$ & $30.2 \pm 8.7$ & $29.1 \pm 10.0$ & $31.2 \pm 11.4$ \\
\hline P-value & - & $<0.001^{\mathrm{d}}$ & 0.14 & $0.02^{f}$ & $<0.001^{\mathrm{d}}$ & $<0.001^{\mathrm{d}}$ \\
\hline $\begin{array}{l}\text { Serum ALP at study } \\
\text { entry, IU/L }\end{array}$ & $171.3 \pm 100.5$ & $170.4 \pm 87.4$ & $176.1 \pm 44.7$ & $177.0 \pm 50.8$ & $162.0 \pm 64.4$ & $191.4 \pm 153.5$ \\
\hline P-value & - & 0.94 & 0.86 & 0.89 & 0.64 & 0.46 \\
\hline \multicolumn{7}{|l|}{$\begin{array}{l}\text { HBV DNA at study } \\
\text { entry }\end{array}$} \\
\hline Detectable & $174(58.8)$ & $59(57.3)$ & $6(37.5)$ & $4(66.7)$ & $21(55.3)$ & $14(66.7)$ \\
\hline Undetectable & $122(41.2)$ & $44(42.7)$ & $10(62.5)$ & $2(33.3)$ & $17(44.7)$ & $7(33.3)$ \\
\hline P-value & - & 0.88 & 0.24 & 0.78 & 0.75 & 0.6 \\
\hline \multicolumn{7}{|c|}{$\begin{array}{l}\text { Abbreviations: AST, aspartate transaminase; ALT, alanine transaminase, ALP, alkaline phosphatase; HBV, hepatitis B virus; } \\
\text { b Data are presented in No. } \% \text { or Mean } \pm \text { SD. } \\
\text { c Estimated risk factors for elevation of serum ALT levels were compared with the cases of persistently normal ALT levels } \\
\text { d Significant at P value }<0.001 \text {. } \\
\text { e Significant at P value }<0.01 \text {. } \\
\text { f Significant at P value }<0.05 \text {. }\end{array}$} \\
\hline
\end{tabular}




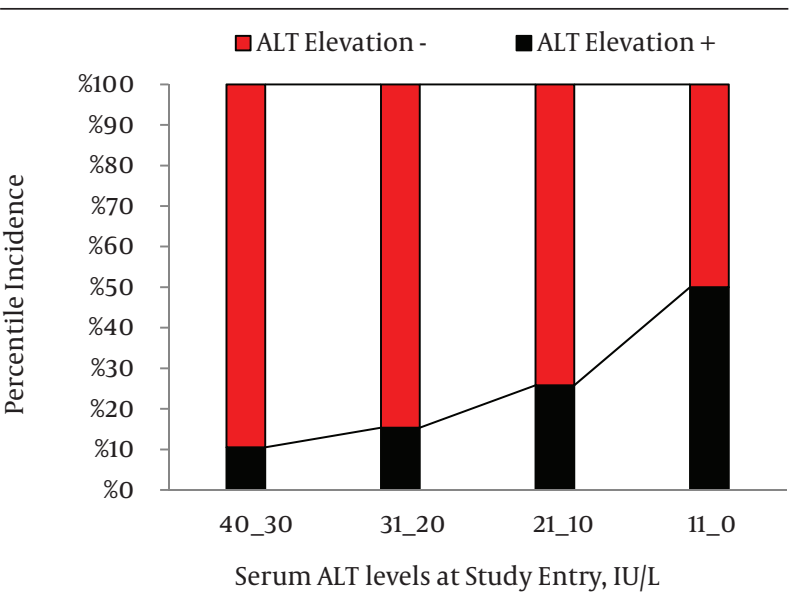

Figure 1. Association Between Incidence of Serum ALT Elevations and ALT levels at Study Entry (IU/L)

A paired-samples t-test also revealed mild elevation in ALT mean levels in comparison to ALT measures at study entry ( $26.5 \pm 16.0$ vs. $24.0 \pm 9.4 \mathrm{IU} / \mathrm{L}, \mathrm{P}<0.001)$. No significant association was found between; terminal levels of ALT levels and age at study entry, age at study ending, or HBV DNA measures at study entry $(\mathrm{P}=0.09,0.17$, and 0.15 , respectively).

\subsection{Natural Course of Inactive Carrier State}

\subsubsection{Chronic Hepatitis $B$}

By the end of the study, 15 (3.76\%) patients had developed HBeAg negative chronic hepatitis B (CHB); with an incidence rate of 0.42 per 100 person-years. Mean levels of ALT at the time of the CHB patients' diagnosis was 70.3 $\pm 27.4 \mathrm{IU} / \mathrm{L}$; ranging from 47 to $131 \mathrm{IU} / \mathrm{L}$. In addition, there was no significant difference in ALT levels between male and female patients $(67.5 \pm 29.6 \mathrm{IU} / \mathrm{L}$ and $81.3 \pm 14.6 \mathrm{IU} / \mathrm{L}$, respectively, $\mathrm{P}=0.21$ ). ALT levels at the time of diagnosis of CHB in 8, 2, 4 and 1 patient were within 1-1.5 $\times$ ULN, 1.5-2 $\times$ ULN, $2-3 \times$ ULN, and 3-4 $\times$ ULN, respectively. Serum HBV DNA level at the time of diagnosis of CHB varied widely from 3.004 to $>7.2 \times 10^{7} \mathrm{IU} / \mathrm{mL}$. Levels of ALT had a significant association with the natural logarithm of serum HBV DNA $(P=0.001$, adjusted R square $=0.62)($ Figure 2$)$. Probable underlying risk factors for the progression of inactive $\mathrm{HBV}$ carrier state to $\mathrm{HBeAg}$ negative $\mathrm{CHB}$ were evaluated and described in Table 2. Interestingly, we found that patients with history of an episode of ALT elevation to $>$ ULN and HBV DNA $<2000 \mathrm{IU} / \mathrm{mL}$ (i.e. without an increase in HBV replication), in comparison to patients with persistently normal ALT levels, were at 8-fold higher risk for the development of HBeAg negative $\mathrm{CHB}$ (incidence rate $11.1 \%$ vs. $1.3 \%, \mathrm{RR}=8.3,95 \% \mathrm{CI}=2.7-25.6, \mathrm{P}$ $<0.001)$. Mean interval between the first episode of ALT elevation (with HBV DNA $<2000 \mathrm{IU} / \mathrm{mL}$ ) and the development of CHB was $58.1 \pm 23.5$ months; and this varied from 13 to 88 months.
Table 2. Estimated Risk Factors for Development of Chronic Hepatitis B in Inactive HBV Carrier State a, b, c

\begin{tabular}{|c|c|c|c|}
\hline Risk Factors & $\begin{array}{l}\text { HBeAg } \\
\text { Negative } \\
\text { CHB }(n=15)\end{array}$ & $\begin{array}{l}\text { Inactive } \\
\text { Carrier State } \\
(\mathbf{n}=338)\end{array}$ & P value \\
\hline Gender & & & 0.11 \\
\hline Male & 12 & 192 & \\
\hline Female & 3 & 148 & \\
\hline Positive family $\mathrm{Hx}$ & $\begin{array}{c}10 \text { of } 13 \\
(76.9)\end{array}$ & $\begin{array}{c}152 \text { of } 194 \\
(78.4)\end{array}$ & 1.000 \\
\hline $\begin{array}{l}\text { Age at study entry, } \\
\text { y }\end{array}$ & $31.3 \pm 12.4$ & $35.5 \pm 11.6$ & 0.17 \\
\hline $\begin{array}{l}\text { Age at study ter- } \\
\text { mination, } y\end{array}$ & $40.9 \pm 13.1$ & $44.4 \pm 12.0$ & 0.27 \\
\hline $\begin{array}{l}\text { Detectable serum } \\
\text { HBV DNA at study } \\
\text { entry }\end{array}$ & 8 of $15(53.3)$ & $\begin{array}{c}203 \text { of } 340 \\
(59.7)\end{array}$ & 0.71 \\
\hline $\begin{array}{l}\text { Mean HBV DNA at } \\
\text { study entry, IU/mL }\end{array}$ & $831.7 \pm 991.3$ & $687.4 \pm 887.6$ & 0.818 \\
\hline $\begin{array}{l}\text { Serum AST at } \\
\text { study entry, IU/L }\end{array}$ & $23.4 \pm 8.5$ & $24.5 \pm 7.7$ & 0.63 \\
\hline $\begin{array}{l}\text { Serum ALP at } \\
\text { study entry, IU/L }\end{array}$ & $183.6 \pm 181.2$ & $170.6 \pm 92.4$ & 0.65 \\
\hline $\begin{array}{l}\text { Serum ALT at } \\
\text { study entry, IU/L }\end{array}$ & $24.4 \pm 11.8$ & $23.8 \pm 9.3$ & 0.8 \\
\hline $\begin{array}{l}\text { Hx of non-HBV } \\
\text { related ALT eleva- } \\
\text { tion }\end{array}$ & 11 of $15(73.3)$ & $\begin{array}{c}88 \text { of } 384 \\
(22.9)\end{array}$ & $\begin{array}{c}<0.001 \\
\mathrm{~d}\end{array}$ \\
\hline \multicolumn{4}{|c|}{$\begin{array}{l}\text { a Abbreviations: } \mathrm{CHB} \text {, chronic hepatitis } \mathrm{B} \text {; HBV, hepatitis B virus; } \mathrm{AST} \text {, } \\
\text { aspartate transaminase; ALT, alanine transaminase; ALP, alkaline } \\
\text { phosphatase; } \mathrm{Hx} \text {, history. } \\
\text { b Data are presented in No. (\%) or Mean } \pm \mathrm{SD} \text {. } \\
\text { c Non-HBV related ALT elevation, elevated serum ALT Levels in absence } \\
\text { of HBV replication (ie, } \mathrm{HBV}<2000 \mathrm{IU} / \mathrm{mL} \text { ) } \\
\text { d significant at } \mathrm{P} \text { value }<0.001 \text {. }\end{array}$} \\
\hline
\end{tabular}

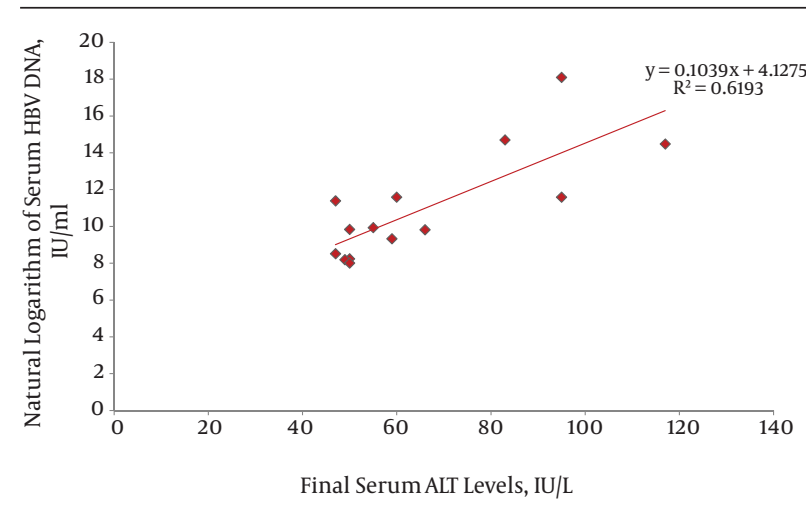

Figure 2. Association of Serum ALT Levels and Natural Logarithm of Serum HBV DNA in Patients with Chronic Hepatitis B

\subsubsection{HBsAg Seroclearance}

By the end of the study, negative results for serum HB- 
sAg were observed in 48 patients. Finally, 43 (10.8\%) patients maintained negative HBsAg to the end of the study and for a mean period of $24.6 \pm 26.3$ months; which revealed an annual incidence rate of $1.21 \%$ for seroclearance of HBsAg. In total, 12 patients also became seropositive for antibodies to hepatitis B surface antigens (HBsAb). No significant association was found between HBsAg seroclearance and gender, age, levels of AST, ALT, or HBV DNA, at study entry, or ALT fluctuations through the follow-ups $(\mathrm{P}>0.05)$.

\subsubsection{Liver-Related Complications}

Four patients ( 1 female, 3 males) developed cirrhosis by the end of the study. Two of the cases developed cirrhosis in the setting of $\mathrm{CHB}$; while the remaining two patients were in an inactive carrier state. Moreover, one 37 year-old male patient with no history of ALT elevation developed HCC.

\section{Discussion}

In this long-term study, we followed up a cohort of 399 inactive HBsAg carrier patients with; positive serum HBsAg, negative $\mathrm{HBeAg}$, low levels of $\mathrm{HBV}$ replication (serum HBV DNA $<2000 \mathrm{IU} / \mathrm{mL}$ ), and persistently normal levels of serum ALT ( $<40 \mathrm{IU} / \mathrm{L})$ at study entry. Through nine years of follow-up, we aimed to evaluate the incidence and prognostic values of serum ALT fluctuations on the development of chronic HBeAg negative hepatitis B, HBsAg seroclearance, and liver-related complications. Evaluation of the natural course of ALT fluctuations among patients with an inactive HBV carrier state is of value. According to the current guidelines $(4,5)$, ALT is the firstline modality to follow up these patients. Moreover, it has repeatedly been reported that higher levels of serum ALT in HBV chronic infection are associated with a higher risk for the incidence of hepatic histopathologic changes and cirrhosis $(20,21)$, and hepatocellular carcinoma (21-23). In our study, patients with a HBV inactive carrier state were at annual risk of $2.9 \%$ for elevation of ALT to > ULN measures. Through the nine years of follow-up, $25.8 \%$ of the patients experienced at least one episode of ALT elevation. However, in $63.1 \%$ of cases of ALT elevation, enzyme levels decreased to normal levels within six months. In addition, in $84.5 \%$ of the patients with ALT elevation, maximal serum levels of ALT were within 1-2 $\times$ ULN measures. And in $79.6 \%$ of the cases, only a single episode of ALT elevation was observed through the follow-ups. Finally, in $84.4 \%$ of the cases, elevations of ALT levels were not accompanied by increased HBV replication; ie, serum HBV PCR measures were $<2000 \mathrm{IU} / \mathrm{mL}$. The incidence of ALT elevation was significantly higher in patients of male gender, age less than 45 years, and higher levels of serum ALT at study entry.

Interpretation of fluctuations in serum ALT levels in HBV chronic carriers may be challenging, since eleva- tions of ALT levels are a frequent finding in the general population, and may be associated with etiologies other than viral infections. Cross-sectional studies on different populations estimate that the prevalence of ALT > ULN could be within $8-30 \%$ of the general population (24-31). Irrespective of viral hepatitis, the risk factors for elevation of serum ALT levels include; male gender (27-29, 31), age (24), obesity (25-31), diabetes $(25,28,30,31)$, hyperlipidemia $(24,25,28,30,31)$, moderate to heavy alcohol drinking $(26,29,31)$, and drug-induced liver injury (DILI) $(32,33)$. Depending on the methodology and the population of the study, non-alcoholic fatty liver disease (NAFLD) is estimated to be the etiology in $24-77 \%$ of cases of serum ALT elevations $(24,28,30,34)$. In a study on HBeAg negative patients with elevated ALT levels and low level viremia, there were symptoms of hyperglycemia and hyperlipidemia detected in $24.5 \%$ and $49 \%$ of the patients, respectively. Liver biopsy assessments also showed the presence of NAFLD and CHB in $38.8 \%$ and $26.6 \%$ of the patients, respectively (35).

The findings of this study suggest that the majority of patients with a HBV inactive carrier state maintain persistently normal levels of serum ALT through long-term follow-ups. However, elevations of ALT levels to > ULN measures are common findings in these patients. ALT elevations are usually within 1-2 $\times$ ULN, and these are not associated with an increase in $\mathrm{HBV}$ replication, as enzyme levels often decrease to normal levels within six months and a recurrence of enzyme elevation in patients is rare. These findings are similar to the results of recently published data (36), which suggests a favorable natural course of serum ALT level fluctuations in HBV inactive carriers.

This study also suggests that the annual incidence of HBeAg-negative CHB in patients with HBV inactive carrier state is $0.42 \%$, with a cumulative incidence of $3.76 \%$ through the study. This rate seems significantly lower than previously reported results in other population studies which estimated the annual incidence rate of 1-3\% for developing this outcome (13). A possible explanation for this discrepancy may be due to the inclusion criteria of this study; i.e. treatment-naïve HBV inactive carrier state, no alcohol use, no concurrent medical disease, and normal abdominal ultrasonography and laboratory tests at study entry. One other possibility could be the difference in HBV genotypes affecting the population studies. It has previously been reported that the HBV genotype among our population study (Iran) is genotype D of the virus $(37,38)$, which is reported to be associated with a more favorable course of the disease $(16,18,39)$.

In this study, patients with non-HBV related ALT elevation (i.e. ALT $>U L N$, HBV DNA $<2000 \mathrm{IU} / \mathrm{mL}$ ) and patients with HBeAg negative CHB (i.e. ALT $>$ ULN, HBV DNA $>2$ $000 \mathrm{IU} / \mathrm{mL}$ ) did not show any significant difference in maximal serum ALT levels at the time of enzyme elevation, or in the duration of the episode. This suggests that 
these two items may not predict the development of CHB in patients with a HBV inactive carrier state and elevated levels of serum ALT. However, in patients previously diagnosed as CHB, serum ALT levels showed a positive statistical correlation with the natural logarithm of serum HBV DNA measured by PCR assays. An interesting finding of this study was that $73 \%$ of CHB cases (11 out of 15 ) had a positive history for elevation of ALT levels while concurrent serum HBV DNA measures were $<2000 \mathrm{IU} / \mathrm{mL}$. This finding suggests that inactive HBV carriers, who have experienced an episode of non-HBV related ALT elevation, in comparison to persistently normal levels of ALT, are at an 8-fold higher risk for the development of HBeAg negative $\mathrm{CHB}$ in future follow-ups. The development of $\mathrm{CHB}$ occurred after a mean interval of 58.1 \pm 23.5 months after the first episode of non-HBV related ALT elevation.

One explanation for this phenomenon might be the possibility that an active inflammatory process in the liver tissue may persist in the absence of HBV viremia and even after normalization of serum ALT levels. Another possibility is that, there may be an underlying non-HBV related pathogenesis in these patients, which increases their vulnerability to reactivation of the HBV infection into chronic hepatitis. However, for a more clear understanding of this phenomenon, further investigations may be required to confirm the findings of this study; and to probe for the expected pathogenesis of this process.

\section{Acknowledgements}

The authors of this article would like to express their sincere gratitude to Dr Mohammad Abdollahi MD and Ms. Hoda Beyram for their generous assistance with the study.

\section{Authors' Contribution}

All authors contributed equally in the study design, data collection, and manuscript preparation.

\section{Financial Disclosure}

The authors declared that they had no conflict of interest regarding this work.

\section{Funding/Support}

This study had no funding source.

\section{References}

1. Chen JD, Yang HI, Iloeje UH, You SL, Lu SN, Wang LY, et al. Carriers of inactive hepatitis B virus are still at risk for hepatocellular carcinoma and liver-related death. Gastroenterology. 2010;138(5):1747-54.

2. Bortolotti F, Guido M, Bartolacci S, Cadrobbi P, Crivellaro C, Noventa $\mathrm{F}$, et al. Chronic hepatitis B in children after e antigen seroclearance: final report of a 29-year longitudinal study. Hepatology. 2006;43(3):556-62.

3. Sharma SK, Saini N, Chwla Y. Hepatitis B virus: inactive carriers. Virol J. 2005;2:82.
4. European Association For The Study Of The L. EASL clinical practice guidelines: Management of chronic hepatitis B virus infection. J Hepatol. 2012;57(1):167-85.

5. Lok AS, McMahon BJ. Chronic hepatitis B: update 2009. Hepatology. 2009;50(3):661-2.

6. Papatheodoridis GV, Manolakopoulos S, Liaw YF, Lok A. Follow-up and indications for liver biopsy in HBeAg-negative chronic hepatitis B virus infection with persistently normal ALT: a systematic review. J Hepatol. 2012;57(1):196-202.

7. Fateen AA, Shahin RY, Farres MN, Eldeeb MA, Amer HA. Assessment of hepatic fibrosis and necroinflammation among inactive HBsAg carriers in Egypt. Ann Hepatol. 2012;11(4):464-70.

8. Maimone S, Calvaruso V, Pleguezuelo M, Squadrito G, Amaddeo $\mathrm{G}$, Jacobs M, et al. An evaluation of transient elastography in the discrimination of HBeAg-negative disease from inactive hepatitis B carriers. J Viral Hepat. 2009;16(11):769-74.

9. Martinot-Peignoux M, Boyer N, Colombat M, Akremi R, Pham BN, Ollivier S, et al. Serum hepatitis B virus DNA levels and liver histology in inactive HBsAg carriers. J Hepatol. 2002;36(4):543-6.

10. Iloeje UH, Yang HI, Su J, Jen CL, You SL, Chen CJ, et al. Predicting cirrhosis risk based on the level of circulating hepatitis B viral load. Gastroenterology. 2006;130(3):678-86.

11. Iloeje UH, Yang HI, Chen CJ. Natural history of chronic hepatitis B: what exactly has REVEAL revealed? Liver Int. 2012;32(9):1333-41.

12. Sporea I, Nicolita D, Sirli R, Deleanu A, Tudora A, Bota S. Assessment of noninvasive liver stiffness in inactive HBsAg carriers by transient elastography: Fibroscan in inactive HBsAg carriers. Hepat Mon. 2011;11(3):182-5.

13. Villa E, Fattovich G, Mauro A, Pasino M. Natural history of chronic HBV infection: special emphasis on the prognostic implications of the inactive carrier state versus chronic hepatitis. Dig Liver Dis. 2011;43 Suppl 1:S8-14.

14. Chu CM, Liaw YF. Incidence and risk factors of progression to cirrhosis in inactive carriers of hepatitis B virus. Am J Gastroenterol. 2009;104(7):1693-9.

15. Chu CM, Liaw YF. Spontaneous relapse of hepatitis in inactive HBsAg carriers. Hepatol Int. 2007;1(2):311-5.

16. Tohme RA, Bulkow L, Homan CE, Negus S, McMahon BJ. Rates and risk factors for hepatitis $B$ reactivation in a cohort of persons in the inactive phase of chronic hepatitis B-Alaska, 2001-2010. J Clin Virol. 2013;58(2):396-400.

17. Tseng TC, Liu CJ, Yang HC, Su TH, Wang CC, Chen CL, et al. Serum hepatitis B surface antigen levels help predict disease progression in patients with low hepatitis B virus loads. Hepatology. 2013;57(2):441-50.

18. Chu CM, Liaw YF. Predictive factors for reactivation of hepatitis B following hepatitis B e antigen seroconversion in chronic hepatitis B. Gastroenterology. 2007;133(5):1458-65.

19. Sali S, Alavian SM, Foster GR, Keyvani H, Mehrnoosh L, Moham madi N. Influencing Factors on the Outcome and Prognosis of Patients With HBV Infction: Seven Years Follow-up. Hepat Mon 2013;13(7).

20. Alam S, Ahmad N, Mustafa G, Shrestha A, Alam AK, Khan M. Evaluation of normal or minimally elevated alanine transaminase, age and DNA level in predicting liver histological changes in chronic hepatitis B. Liver Int. 2011;31(6):824-30.

21. Tai DI, Lin SM, Sheen IS, Chu CM, Lin DY, Liaw YF. Long-term outcome of hepatitis B e antigen-negative hepatitis B surface antigen carriers in relation to changes of alanine aminotransferase levels over time. Hepatology. 2009;49(6):1859-67.

22. Hann HW, Wan S, Myers RE, Hann RS, Xing J, Chen B, et al. Comprehensive analysis of common serum liver enzymes as prospective predictors of hepatocellular carcinoma in HBV patients. PLOS One. 2012;7(10).

23. Chen CF, Lee WC, Yang HI, Chang HC, Jen CL, Iloeje UH, et al Changes in serum levels of HBV DNA and alanine aminotransferase determine risk for hepatocellular carcinoma. Gastroenterology. 2011;141(4):1240-8.

24. Gunji T, Matsuhashi N, Sato H, Iijima K, Fujibayashi K, Okumura $\mathrm{M}$, et al. Risk factors for serum alanine aminotransferase elevation: A cross-sectional study of healthy adult males in Tokyo, Japan. Dig Liver Dis. 2010;42(12):882-7.

25. Cotler SI, Dhamija MK, Luc B], Siqueira F, Bartram AH, Layden T], et al. The prevalence and clinical correlates of elevated ALT levels 
in an urban Chinatown community. J Viral Hepat. 2010;17(2):14852.

26. Adams LA, Knuiman MW, Divitini ML, Olynyk JK. Body mass index is a stronger predictor of alanine aminotransaminase levels than alcohol consumption. J Gastroenterol Hepatol. 2008;23(7 Pt 1):1089-93.

27. Papatheodoridis GV, Goulis J, Christodoulou D, Manolakopoulos S, Raptopoulou M, Andrioti E, et al. High prevalence of elevated liver enzymes in blood donors: associations with male gender and central adiposity. Eur J Gastroenterol Hepatol. 2007;19(4):2817.

28. Chen $\mathrm{CH}$, Huang MH, Yang JC, Nien CK, Yang CC, Yeh YH, et al. Prevalence and etiology of elevated serum alanine aminotransferase level in an adult population in Taiwan. J Gastroenterol Hepatol. 2007;22(9):1482-9.

29. Ioannou GN, Boyko EJ, Lee SP. The prevalence and predictors of elevated serum aminotransferase activity in the United States in 1999-2002. Am J Gastroenterol. 2006;101(1):76-82.

30. Pendino GM, Mariano A, Surace P, Caserta CA, Fiorillo MT, Amante A, et al. Prevalence and etiology of altered liver tests: a population-based survey in a Mediterranean town. Hepatology. 2005;41(5):1151-9.

31. Clark JM, Brancati FL, Diehl AM. The prevalence and etiology of elevated aminotransferase levels in the United States. Am J Gastroenterol. 2003;98(5):960-7.

32. Leise MD, Poterucha JJ, Talwalkar JA. Drug-induced liver injury.
Mayo Clin Proc. 2014;89(1):95-106.

33. Tajiri K, Shimizu Y. Practical guidelines for diagnosis and early management of drug-induced liver injury. World J Gastroenterol. 2008;14(44):6774-85.

34. Jamali R, Khonsari M, Merat S, Khoshnia M, Jafari E, Bahram Kalhori A, et al. Persistent alanine aminotransferase elevation among the general Iranian population: prevalence and causes. World $J$ Gastroenterol. 2008;14(18):2867-71.

35. Demir K, Akyuz F, Ozdil S, Aksoy N, Kaymakoglu S, Poturoglu S, et al. What is the reason of elevated alanine aminotransferase level in HBeAg negative patients with low viremia: NAFLD or chronic hepatitis? Ann Hepatol. 2007;6(2):92-6.

36. Tong MJ, Trieu J. Hepatitis B inactive carriers: clinical course and outcomes. J Dig Dis. 2013;14(6):311-7.

37. Bahramali G, Sadeghizadeh M, Amini-Bavil-Olyaee S, Alavian SM, Behzad-Behbahani A, Adeli A, et al. Clinical, virologic and phylogenetic features of hepatitis B infection in Iranian patients. World J Gastroenterol. 2008;14(35):5448-53.

38. Alavian SM, Keyvani H, Rezai M, Ashayeri N, Sadeghi HM. Preliminary report of hepatitis B virus genotype prevalence in Iran. World J Gastroenterol. 2006;12(32):5211-3.

39. Kumar A, Kumar SI, Pandey R, Naik S, Aggarwal R. Hepatitis B virus genotype $\mathrm{A}$ is more often associated with severe liver disease in northern India than is genotype D. Indian J Gastroenterol. 2005;24(1):19-22. 